Brandeis | цввая

brandeis.edu/j-caste
CASTE: A Global Journal on Social Exclusion Vol. 2 No. 2 pp. 39I-396

October-November 2021

ISSN 2639-4928

https://doi.org/10.26812/caste.v2i2.344

\title{
Dalit-Bahujan Feminism: A Newly Emerging Discourse
}

\author{
Kancha Ilaiah Shepherd \\ Former Director \\ Centre for the Study of Social Exclusion \\ and Inclusive Policy \\ Maulana Azad National Urdu University, \\ Hyderabad \\ E-mail:kanchailaiah@yahoo.co.in
}

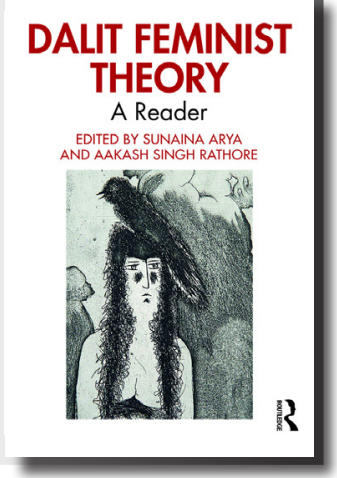

\section{Dalit Feminist Theory: A Reader}

\author{
Edited by: \\ Sunaina Arya and Aakash Singh Rathore \\ Routledge India, 2020
}

Dalit Feminist Theory: A Reader is a collection of essays written by feminist writers in India. Feminism as a school of thought emerged in India in the early 1980s and since then, several scholarly works have been produced by feminists. Towards the beginning of the movement, there were two distinct groups of scholars, both educated in the English medium. The common factor in both groups was that the scholars all came from the $d w i j a^{1}$ castes (Brahmin, Bania, Kayastha, Khatri and very few Kshatriya). The difference lay in the political positions which informed their standpoints - one group were Liberal Democrats, the others were Marxist feminists. After the 1990 Mandal movement, a third ideological school started to emerge. They foregrounded caste as a theoretical framework in understanding man-woman relations in India, as opposed to their predecessors who only theorized from the framework of class and democratic institutions.

The editors of this book have chosen to reproduce several essays written by both Marxist and Liberal Democratic, non Dalit-bahujan women writers and in doing so have made clear their Dalit feminist position. Sunaina Arya is a young Dalit woman Ph.D candidate and research scholar in the field of Philosophy. The

${ }^{1}$ Dwija is a term for the people from the castes considered higher in the caste strata, who regard themselves as twice-born, and hence a pure form of Hindus.

(C) 202I Kancha Ilaiah Shepherd. This is an open access article distributed under the terms of the Creative Commons Attribution License, which permits unrestricted use, distribution, and reproduction in any medium, provided the original author(s) and source are credited. 
second editor, Aakash Singh Rathore, whom I recently discovered in the academic domain, despite having come from Kshatriya family background, collaborated with her. What is interesting to note is they took a very strong Dalit position, in this case a Dalit feminist position. Generally, dwija male intellectuals in India or abroad, write on women's issues without grounding themselves on a serious feminist position. I am glad that Rathore being a Kshatriya, co-edited this book with an emerging Dalit feminist philosopher.

In 2012, on the occasion of my retirement from Osmania University, Susie Tharu, an early leading feminist of India, described me as a 'Male Sister of Feminism'. ${ }^{2}$ I am not sure whether I deserve that description. But it is true that from the genesis of the anti-caste movement, Dalit-bahujan leaders like Mahatma Phule, Babasaheb Ambedkar and Periyar Ramasamy all centered on the liberation of women. Dalitbahujan feminism has its roots in the writings and work of Savitribai Phule and Mahatma Jyotirao Phule, who were founding leaders and educators who worked to bring about caste consciousness among the depressed castes in the nineteenth century. In the twentieth century, Ambedkar took a clear theoretical stand on man-woman equality, including property rights for women. His stance on sex work, like his stand on Aryan migration and existence of race relations in India, are coming up for contested discussion in the present times. ${ }^{3}$

In this volume, the position of Nivedita Menon (the only Shudra Nair woman feminist of repute I know) on sex work is discussed at length. Arya and Rathore have positioned themselves for abolishing sex work, which has historically dehumanized Dalit-bahujan women as a consequence of their position on the margins of society. It is not dwija women or highly educated women who are employable in other sectors, but Dalit-bahujan women who are forced to take up sex work as a job. Sex work in the Devadasi $i^{4}$ form or bar sex work form is that which Dalit women are forced into; whereas globally, many women who are employable in other sectors might chose sex work as work for livelihood (Chapter 8). Importantly, the inherent caste system complicated and spiritualised sex work in India.

We must also examine that while sex work is mainly the job of Dalit-bahujan women in India, permanent widowhood-in some cases from childhood days onwards, with a condemned life in Kashi dens is often the only a life of Brahmin or other dwija women (as brought to light by the film Water) ${ }^{5}$ - this too dehumanises women as human beings. The condemned widowhood and Brahminic child marriage,

${ }^{2}$ Kancha Ilaiah, Understanding Feminism: On Being a Male Sister of Feminism, Frontier, Vol. 46, no. 18, November 10-16, 2013. Retrieved from https://www.frontierweekly.com/archive/ vol-number/vol/vol-46-2013-14/46-18/46-18-On\%20Being\%20a\%20Male $\% 20$ Sister $\% 20$ of $\% 20 \mathrm{Feminism}$.html

${ }^{3}$ See my Review of Tony Joseph's book Early Indians (2018) with a title, Early India: Goats and Brahmins, Mainstream, Vol. LVIII, No. 29, New Delhi, July 4, 2020. Retrieved from https:// www.mainstreamweekly.net/article9591.html

${ }^{4}$ Devadasi is a tradition of devoting young Dalit girls to temples in name of service to the God, where eventually they are sexually exploited by the temple priests and have no return from a sexually exploitative living. Dev literally translates as god and Dasi as female slave.

${ }^{5}$ Water is a Bollywood movie released in 2007, available at https://www.youtube.com/ watch? $\mathrm{v}=\mathrm{hP} 35 \mathrm{Okfv} 0 \mathrm{~m} 8$ 
and Sati were more barbaric than sex work. However, today these institutions are gradually being abolished. The dwija women are among the most educated and most globally mobile women from India. The Dalit-bahujan women are denied such opportunities (Part III).

When I characterised the patriarchies in India as 'Dalit-bahujan Democratic Patriarchy' and 'Brahminic Patriarchy' based on their open productive and reproductive participatory man-woman relations, many Dalit feminists also disagreed with me. ${ }^{6}$ The dwija feminists condemned me as a binarist in everything. But is it not a fact that historically the Dalit, Adivasi, ${ }^{7}$ Shudra women never had to live as permanent widows? Is it not true, that the dwija women not only lived as permanent widows from childhood days and had to go through Sati-a brutal murder of women till the British made laws to abolish such a system? Do dwija women living in the villages have the right to work in the production fields along with other male members in India even now? They do not.

Does that right not exist for all Dalit-bahujan women even today (see Chapters 5 and 9), unless they are brahmanized? This is uncritical support of a culture which disallows women to participate in productive work with other men based on the misogynistic premise that women are promiscuous. This brahmanic practice is also observed within Muslim communities. The culture of not allowing women productive work has caused destruction of their creative energies and has kept India underdeveloped when compared to China, its neighbouring country.

However, Chinese women under communist patriarchy are also prevented from holding higher positions in productive work. The communist feminists of India did not examine these practices of communist countries. In India, the liberal constitutional democracy gave scope to dwija women to enter into every state sector. Dwija women have accepted women's reform over caste reform. This has led to Indira Gandhi's emergence as the first woman Prime Minister in the late 1960s. In their professional endeavours, dwija women were aided by English education, introduced by William Carey, the Protestant Missionary reformer and Thomas Babington Macaulay from 1817 to 1834 . Even in the twenty-first century, Dalit-bahujan women have not entered into that English medium education. This is despite Savitribai Phule who gave a call for their English education a long time ago (Chapter 4). The future of the Dalitbahujan-adivasi women depends on the future course of English medium education for girls of those communities.

Dalit-bahujan feminism has to look at the roles of women in productive work and accessibility to public spheres of life. The dwija women now have better exposure to global forms of man-woman relations because of English education, which Dalitbahujan women do not have. But they are still anti-productive labourers because, ironically, educated dwija women think that production is pollution. A cursory examination of dwija women feminist writings would show how indifferent they

${ }^{6}$ Refer to Kancha Ilaiah, Why I am Not a Hindu: A Shudra Critique of Hindutva Philosophy, Calcutta: Samya, 1996, sixth reprint in 2002.

${ }^{7}$ Adivasi is a social term for the Indian constitutional category Scheduled Tribes for the communities who live close to nature, and modern technological resources have not reached them yet. 
are to basic agrarian and artisanal production. Their discourse operates within the Brahminical textual narratives. Their absence in productive fields is as visible as that of Dalit-bahujan women in urban high-end jobs and markets. Therefore, a common English medium school education in government and private schools should be included in the main concerns of Dalit-bahujan feminists.

The present focus of Dalit scholars is around land ownership and reservation-both in education and employment. The regional language education of the Dalit-bahujan community cannot produce high-end thinkers. In the present situation, the Dalit feminist writings by Dalit women would be as weak as the writings of Dalit-bahujan men in the general theoretical discourse. Quality English medium education alone can produce writers and thinkers who produce books of high quality. Dr. B.R. Ambedkar's life and works have proven this.

In regional languages, several Dalit women writers have been producing plenty of writings on the struggles of Dalit women in their day-to-day life - struggles which are unknown to the dwija or the 'upper' Shudra women, as they have not dealt with them at any time in their known history. A few of them-very young Dalit women, not so much Shudra/OBC women, ${ }^{8}$ are writing in English to re-frame the feminist discourse in a fresh way, which rightly is called 'Dalit Feminism' and they describe themselves as Dalit Feminists. Their critique of writings about women, especially Dalit women is a positive development. They are re-examining Phule, Ambedkar and other Dalit writers from their own experience and perception (Part II). This in turn gives new hope for further theoretical possibilities. Sunaina Arya's efforts show this promise. ${ }^{9}$

Dalit-bahujan feminism has a long way to go. It is certainly in its budding stage (Part VI). The only comparable school is that of Black Feminism, which has thrown up many powerful writers in the recent past (Chapter 10). Dalit Feminist Theory: A Reader, though has together a variety of feminist writings in one place, with a useful introduction with a theoretical perspective to develop Dalit-bahujan feminist ideology further (Part IV).

Dalit-bahujan feminism should not operate merely around sexual division of labourers within the home, kitchen, urban markets and urban working spaces as the dwija feminist women's writings do. Dalit feminist theory must not only engage with untouchability which the Dalit women suffer exclusively-but from a position

${ }^{8} \mathrm{OBC}$ is an abbreviation for Other Backward Castes, which a constitutional term for the Shudra communities who are regarded higher over Dalits/'untouchables'/Scheduled Castes but lower than dwij/savarna or so-called upper caste communities, as per Hindu caste hierarchy.

${ }^{9}$ Read Sunaina Arya's 'Theorising Gender in South Asia: Dalit Feminist Perspective', Editorial article in Special Issue on 'Legacy of Gender and Caste Discrimination' of CASTE: A Global Journal on Social Exclusion, Vol. 1, No. 2, October 2020, pp. XI-XXIV; 'Ambedkar as a Feminist Philosopher', chapter 4 in Gender and Racial Justice, Vol. IV of B. R. Ambedkar: A Quest for Justice (five volumes box set), edited by Aakash Singh Rathore, Oxford University Press, 2021, pp. 89-113; 'Dalit or Brahmanical Patriarchy? Rethinking Indian Feminism', CASTE: A Global Journal on Social Exclusion Vol. 1, No. 1, February 2020, pp. 217-228; 'Khader's Feminist Ethic against Imperialism: Proposing a Pluriversal Philosophic Resolve', for the Book Symposium on Decolonizing Universalism: A Transnational Feminist Ethic (OUP, 2019), Journal of Global Ethics, Vol. 16, No. 3, Taylor \& Francis Group. May 2021, pp. 371-387. 
of strength acquired from their productive labourers and the democratic space they inhabit in the village settings of both home and production fields. Though villages are casteist social units as Ambedkar rightly observed, the Dalitwadas ${ }^{10}$ in themselves are democratic, productive and redistributive locations. ${ }^{11}$ Man-woman relations must change across India by using positive structures that already exist in human societies the world over and also within India. Dalitwadas are poor and hardworking, but not exploitative units like Brahminwadas. Productive labourers is an agent of change, but leisure, which the Brahminic women seek as a mode of living, is anti-human.

Dalit feminism must set a new agenda for the feminist ideology of women writers of India. That will be possible when Dalit-bahujan feminists operate outside the theoretical trap that dwija women laid in India - casting the subject of woman as compliant with the Brahminical patriarchal roles. The Brahminic texts should not trap the Dalit-bahujan feminist discourse which should take inspiration from Dalit-bahujan women who made history in their fight with their socio-political and economic circumstances, as well as with oppressive men. The narratives of Dalit-bahujan goddesses like Pochamma and Maisamma are inspiring. Also, there are numerous modern women like Savitribai Phule, Ramabai Ambedkar, Chakali Ilamma (a Dhobi ${ }^{12}$ woman in the Telangana Armed Struggle), ${ }^{13}$ Sammakka and Sarakka who fought the Kakatiya rulers in the thirteenth century, Warangal forest area and became well known figures. There are many such examples in every state in India, who should be Dalitbahujan women's role models.

The only essay that goes against the genre of Dalit feminism, which the editors critically review in this volume is that of Nivedita Menon-'A Critical View on Intersectionality' (Chapter 1). Though Menon is a Shudra Nair woman, she does not accept her Shudra position as socially, spiritually controlled and exploited by Brahminism. That is her weakest point (Part V). Nair women historically suffered inhuman Sambhandham ${ }^{14}$ relations at the hands of Brahmin men. Her de-recognition of intersectionality emerges from her caste blindness, which is located in the Editors' Introduction. ${ }^{15}$ The Marxist feminist school also looked at Indian man-woman relations from a class point of view that does not recognize the Indian specificity of caste.

Dalit-bahujan feminism does not hold much water unless it is rooted in the caste consciousness of the woman writer involved. The women writers who came from upper layer of Shudra (only a few of them are English educated and engaged in writing) like

\footnotetext{
${ }^{10}$ Dalitwada is a term for the segregated settlement (the most infertile land of the village) where only Dalit people are placed, in order to prevent dwija communities from getting polluted by contact with Dalits who are considered lowest in the caste hierarchy. Wada literally means a housing settlement.

${ }^{11}$ See Kancha Ilaiah, Dalitization Not Hinduization, in Why I am Not a Hindu: A Shudra Critique of Hindutva Philosophy, Calcutta: Samya, 1996, sixth reprint in 2002.

${ }^{12}$ Dhobi is a caste traditionally linked with the profession of washermen or laundrymen, which is one among the Dalit/'untouchable' communities.

${ }^{13}$ Sanjeev Gumpenapalli, Chakali Ilamma: A Revolutionary Woman, published in Indian Women In History volume of Feminism in India, December 28, 2017. Retrieved from https:// feminisminindia.com/2017/12/28/remembering-chakali-ilamma/

${ }^{14}$ See Kancha Ilaiah, Untouchable God, Calcutta: Bhatkal \& Sen, 2013.

${ }^{15}$ For details, see Sunaina Arya, An Enquiry into Ambedkar as a Feminist Philosopher. M.Phil dissertation, Centre for Philosophy, New Delhi: Jawaharlal Nehru University, 2017, July 26.
} 
Nair, Reddy, Kamma, Lingayat and Vokkaliga, Naiker, Jat, Patel, Maratha and others did not know how to handle caste consciousness. They face discrimination by dwijas in many spheres in various ways, since they need to work with dwija women given their placement outside the fold of caste-based reservation. But dwija women also do not treat them as equals because they know that they are Shudra. From the lens of food culture, Shudras are meat-eaters with agrarian roots which the dwija women do not have. They face a very strange situation. Under the influence of dwija women, they understand that class position gives them some space to theorise. But class theorisation does not have much meaning in India, as India is primarily a caste society. This is also true for a majority of South Asia. ${ }^{16}$

The remaining essays in this volume are written by either by Dalit women or men, or sympathetic Brahmin women, or women from a Christian background. Many of them claim that they do not believe in religion or birth in a particular religion or caste. But a reader's awareness of the background of the writer makes all the difference. Ignoring religion in the feminist analysis avoids a key lifeline of women. Rather, it is seen that women cling to religion more than men today.

Feminism of the Dalit-bahujan school based on the experience of women, would be different from that of men. Feminist theory emerged based on the 'experience' as the basis of analysis and the 'personal is political'. Nevertheless, Dalit Feminist Theory: A Reader is an important source for many further studies and is indispensable, especially for young research scholars.

${ }^{16}$ See Sunaina Arya, 'Theorising Gender in South Asia: Dalit Feminist Perspective', Editorial article in Special Issue on 'Legacy of Gender and Caste Discrimination' of CASTE: A Global Journal on Social Exclusion, Vol. 1, No. 2, October 2020, pp. XI-XXIV. 